\title{
Environmentally smart animal agriculture and integrated advisory services ameliorate the negative effects of climate change on production
}

\author{
C.T. Kadzere ${ }^{\#}$ \\ Eastern Cape Department of Rural Development and Agrarian Reform, Döhne Agricultural Development Institute, \\ Directorate: Animal and Pasture Sciences Program, Private Bag X15, Stutterheim 4930, Republic of South Africa
}

(Received 3 July 2018; Accepted 12 September 2018; First published online 1 October 2018)

\author{
Copyright resides with the authors in terms of the Creative Commons Attribution 4.0 South African Licence. \\ See: http://creativecommons.org/licenses/by/4.0/za \\ Condition of use: The user may copy, distribute, transmit and adapt the work, but must recognise the authors and the South African \\ Journal of Animal Science.
}

\begin{abstract}
The objective is to discern how Charles Darwin's Origin of species (1859) and the theory of natural selection and evolutionary biology - 'a grain in the balance will determine which individual shall live and which shall die'- are core to achieving environmentally and climate-smart, economically viable, sustainable animal agriculture in a changing climate. Darwin's 'survival of the fittest' theory implies inherent comparative advantage of survivors over the succumbed in any given environment. An animal's phenotype $(P)$ results from interaction of its genotype $(G)$ and the environment $(E)$, expressed as $P=G \times E$. Human migration has transferred livestock breeds from places of origin to distant continents and agro-ecological zones, far from where they have inherent comparative production advantage. For example, crossbreeds of Bos taurus and Bos indicus have higher average performance than median of either parent population. However, the heterotic effect of hybrids is associated with loss of environmental adaptation compared with parent populations. Indigenous breeds, their phenotypes and ecotypes thrive best in distinct environments, ceteris paribus. An environment is the sum total of conditions that influence animal productivity in the habitat. These include nutrition, genetics, disease, exposure to parasites, management practices, climate, rainfall, humidity, heat and cold stressors, and advisory services. Hybrids lose some adaptive capacity compared with parents, and require habitat modifications if they are to express their fullest genetic potential. In the light of this and of global warming challenges to livestock production, it is scientifically and technically prudent to exploit the inherent comparative production advantages of indigenous genotypes, phenotype and ecotypes, when mitigating climate change, more so in low-input animal agriculture systems of sub-Saharan Africa and at similar locations. Climate change poses multidisciplinary challenges that require integrated collaborative cross-discipline research, extension and training to provide holistic solutions.
\end{abstract}

Keywords: Climate-smart, genotype, livestock production efficiency, global warming, indigenous breeds, mitigation strategies

\#E-mail: kadzerect@gmail.com

\section{Introduction}

The ability to convert grass, shrubs and foliage into nutritious food and animal fibres is why ruminants occupy $45 \%$ of the world's ice-free land area (Steinfeld et al., 2006). Livestock production contributes $60 \%$ to $70 \%$ of the global agricultural economy, and has an asset value of $\$ 1.4$ trillion (Thornton et al., 2011; FASS, 2012). The livestock sector value chains employ around 1.3 billion people and supports 600 million farmers in developing countries (Thornton, 2010). Animal agriculture affects and is affected by the environment. This sector is invaluable for public health, social equity and economic growth (World Bank, 2009). Protein of animal origin is 34\% of human diets (Gill \& Smith, 2008; FAO, 2010) and animal products provide $17 \%$ of our energy consumption (Rosegrant et al., 2009).

Livestock contribute to anthropogenic greenhouse gases (GHGs) emissions into the atmosphere, and is implicated in global warming and climate change. The main GHGs of animal agriculture origins include 
carbon dioxide $\left(\mathrm{CO}_{2}\right)$, methane $\left(\mathrm{CH}_{4}\right)$ and nitrous oxide $\left(\mathrm{N}_{2} \mathrm{O}\right)$. Hristov et al. (2013) estimated that $7 \%$ to $18 \%$ of anthropogenic GHGs come from livestock farming, specifically from enteric fermentation, manure, production, transport of feed and changes in land use. Gerber et al. (2013) reported that 29\% of agricultural $\mathrm{N}_{2} \mathrm{O}$ emissions are related to manure and fertilizer application to pastures. The global cattle population is 1.3 billion, of which $50 \%$ are in developing countries, produce 58 million tons of $\mathrm{CH}_{4}$ per year (US EPA, 1994). Beef cattle account for $71 \%$ of the GHGs, dairy $24 \%$ and $5 \%$ is shared among goats, sheep, swine and horses (US EPA, 1990-2000). The global livestock GHGs emissions are estimated to be 7.1 Giga tonnes carbon dioxide equivalents (GT CO 2 eq. $\mathrm{yr}^{-1}$ ), which is $14.5 \%$ of all anthropogenic GHGs (Gerber et al., 2013). GHGs statistics are worrisome and threaten the sustainability of the livestock sector, spurring intense debate on livestock-environment interaction (Otten \& Van den Weghe, 2011). This paper reviews the effects of climate change on livestock production and discusses mitigation options, including the ways in which natural selection as in Darwin (1859) and Von Humboldt (1849) could be useful in adapting livestock farming to climate change in Africa and beyond, and in assessing the best possible extension, research and training approaches to complex challenges posed by global warming to the sector.

The specific objectives are:

i. To explain the causes and effects of climate change on animal agriculture

ii. $\quad$ To review how indigenous breeds have production advantages within their habitats

iii. To figure out how best to exploit the comparative production advantage of indigenous breeds and mitigate climate change

iv. To assess the most suitable method to provide informed effective research, extension and training services and enable farmers to adapt

\section{Greenhouse gases and global warming}

Global warming has two components, namely natural global warming and anthropogenic warming (Figure 1) The natural global warming is caused by i) Earth's orbital changes as explained in Milankovitch Theory, ii) volcanic emissions of GHGs and aerosols, iii) movement of the tectonic plates, and iv) El NiñoSouthern Oscillation (NASA, 2016). Anthropogenic global warming results from human activities that increase GHGs in the atmosphere (Figure 1). Greenhouse gases retain atmospheric infrared radiation causing the 'greenhouse effect' and have different global warming potential (GWP). GWP is the amount of energy a GHG adds to atmospheric warming, relative to the warming effect of the same amount of $\mathrm{CO}_{2}$ (IPCC, 2013). Therefore, although the amount of $\mathrm{CH}_{4}$ in the atmosphere may be lower than that of other GHGs, its higher GWP makes it an effective emission in global warming. The IPCC (2013) reported that $\mathrm{CH}_{4}$ is 20 times more effective than $\mathrm{CO}_{2}$ in trapping atmospheric heat, and concluded that atmospheric concentration of $\mathrm{CH}_{4}$ has increased by $143 \%$ in the past two centuries, owing mainly to human activities including agriculture, forestry, deforestation, transport, energy generation, industry and buildings. The IPCC (2013), Shields and Orme-Evans (2015) and NASA (2016) link increasing GHGs to human activities and to the global warming trend (Figure 2), starting from the industrial revolution in 1750 to date. The National Aeronautics and Space Administration (NASA, 2018) reported that the 16 warmest years since 1880 have been in the last twenty years, and 2016 and 2017 were the warmest years in recorded history (Figure 2).
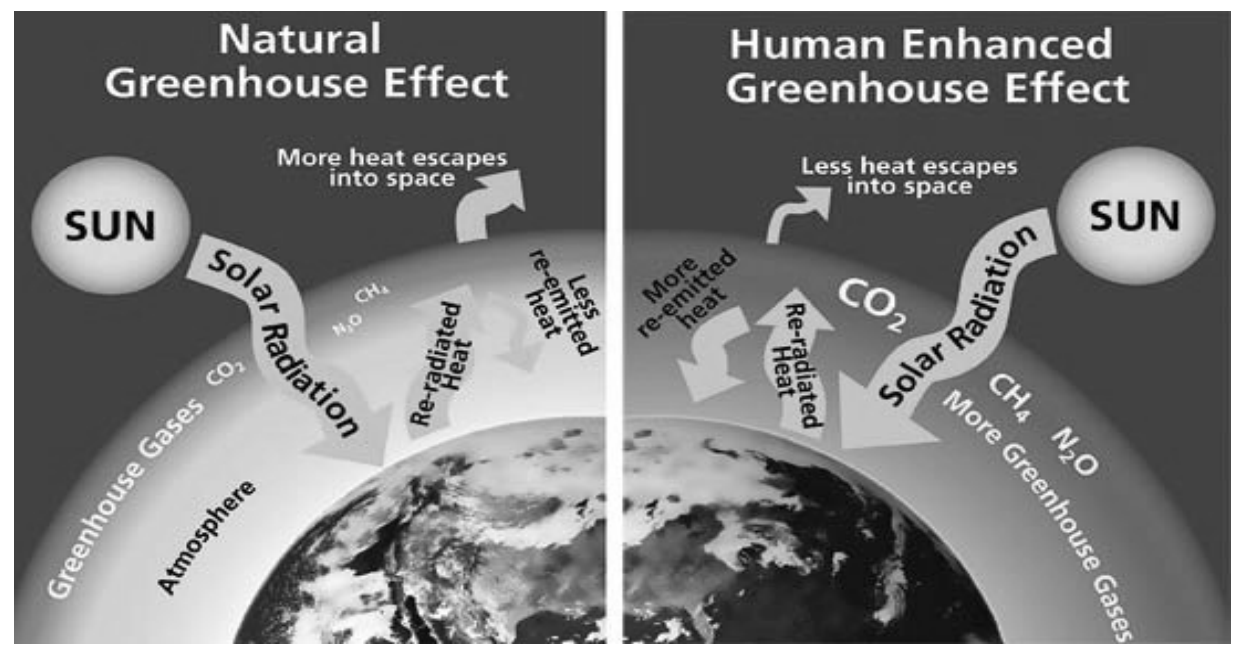

Figure 1 Anthropogenic greenhouse gases, global warming and climate change 


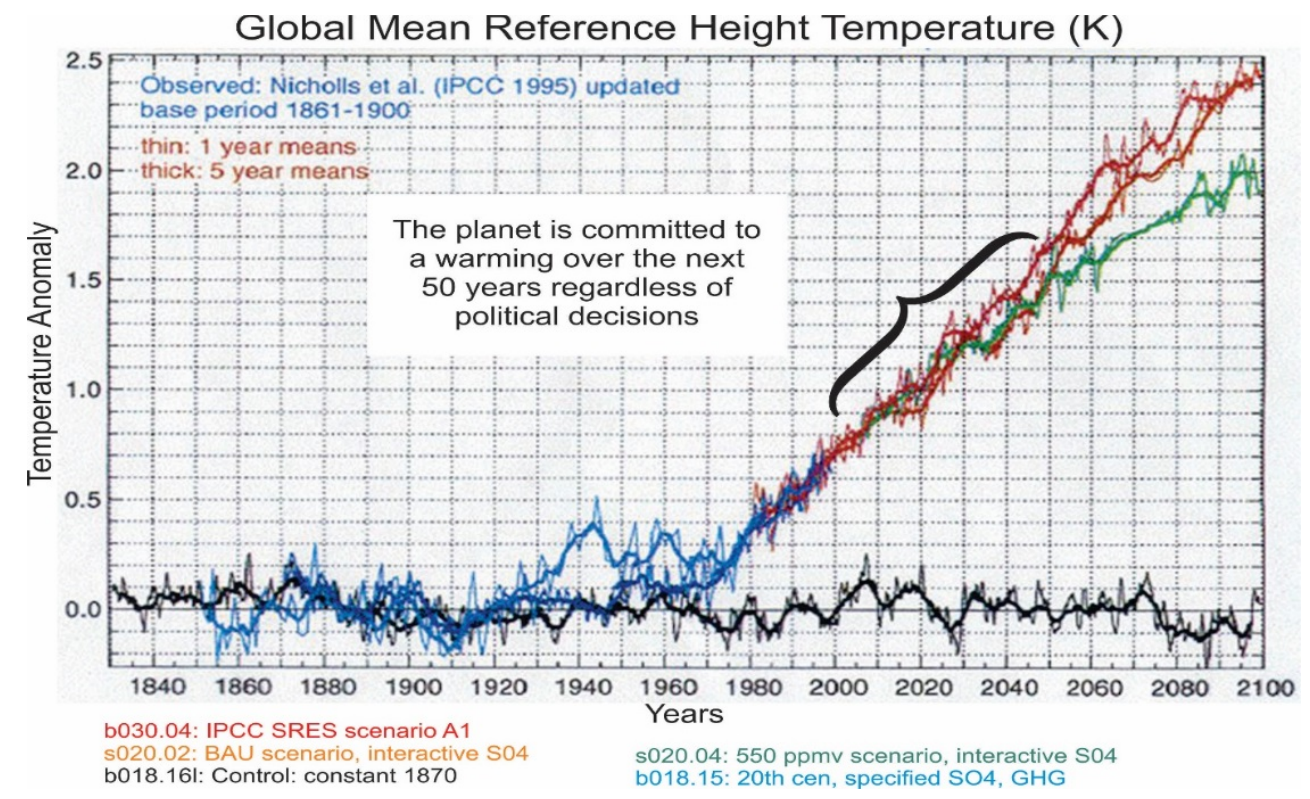

Figure 2 Global temperature trends from 1840 to present, projections to 2100

\section{Impact of global warming on livestock production}

Climate change poses challenges to animal agriculture by providing conditions for heat stress (Figure 3). Heat stress causes behavioural, chemical, physical, nutritional, physiological and metabolic responses in livestock that are geared toward preserving cell integrity and survival. Literature abounds on the effects of heat stress on livestock production, which includes these authors (Dowling, 1955; Huhnke \& Monty, 1976; Escobosa et al., 1984; Parsell \& Lindquist, 1993; Hansen, 2004; Sevi et al., 2001; Kadzere et al., 2002, Perez-Crespo et al., 2008), who are summarized in Figure 3.

The increasing global average temperatures may result in vegetation shifts, for example $\mathrm{C}_{3}$ photosynthesis plants being displaced by the less nutritious $\mathrm{C}_{4}$ photosynthesis plants and in their turn $\mathrm{C}_{4}$ vegetation being displaced by desert-adapted woody crassulacean acid metabolism (CAM) photosynthetic plants, whose stomata remain shut during the day to reduce evapotranspiration water loss, but open at night to collect $\mathrm{CO}_{2}$. Such changes in veldt species composition erode the feed base and affect animal agriculture. The displacement of $\mathrm{C}_{3}$ by $\mathrm{C}_{4}$ photosynthesis forages increases enteric GHGs emissions, because $\mathrm{C}_{4}$ forages have a higher methane conversion rate (MCR) compared with $\mathrm{C}_{3}$ forages (Van Soest, 1994). This higher MCR is attributed to elevated fibre and lignin content of $C_{4}$ plants and to their low levels of non-fibre carbohydrate (Van Soest, 1994), which makes them less digestible (Minson, 1990). 


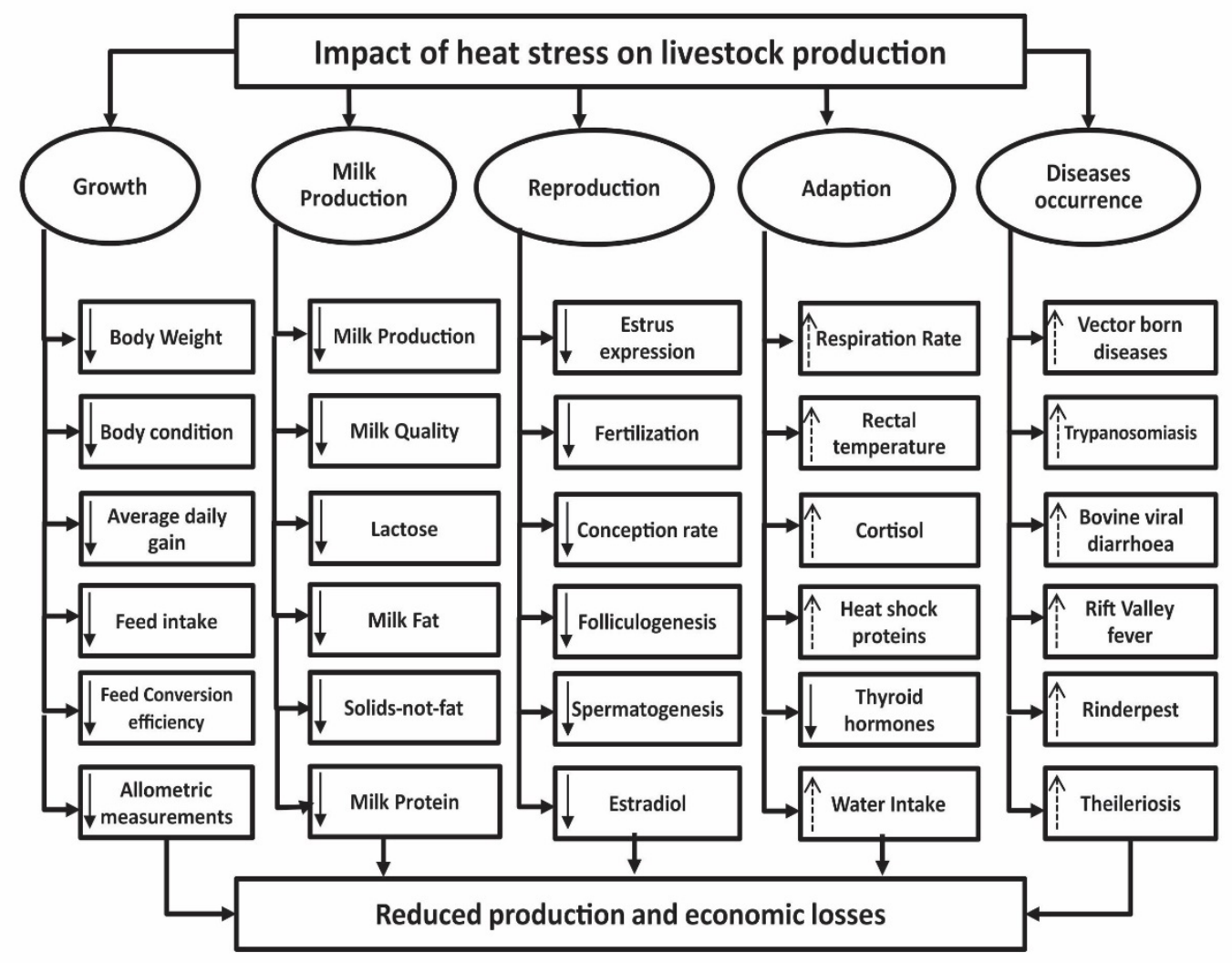

Figure 3 Summary of the effects of heat stress on livestock production Source: Kadzere, 2017

\section{Climate-smart animal agriculture}

Sustainable agriculture is farming that meets current and future societal needs for food and fibre, preserves ecosystems' integrity, is healthy for lives and does so by maximizing the net benefit to society when all costs and benefits are considered, as sketched in Figure 4 (Kadzere, 2017) in sub-Saharan African environments. Indigenous breeds thrive with minimum inputs compared with imported ones. These breeds are pivotal to the development of climate-smart animal agriculture, especially in communal and small-scale farming systems characterized by low investment (Meissner et al., 2013a; 2013b). Animals bred in temperate environments cannot express their fullest genetic potential in African environments owing to heat stress (Figure 3). Global warming exacerbates this. In addition to warm weather, they must contend with factors influencing production in the local environment, including disease, exposure to parasites and seasonal fluctuation of the veldt nutrition base (Figure 5). The quality of natural pasture is closely linked to quantity and distribution of rainfall. Indigenous livestock are adapted to seasonal variation (Meissner et al., 2013b), and may become browsers in periods of poor grass quality.

I hypothesize that animal agriculture would be environmentally and climate-smart if adaptability of indigenous breeds was exploited to the fullest in any given production environment, and especially so in low input, resource-poor livestock systems of sub-Saharan Africa. In input-intensive systems with supplementary feeding, sound animal health and management, the approach would be different. 


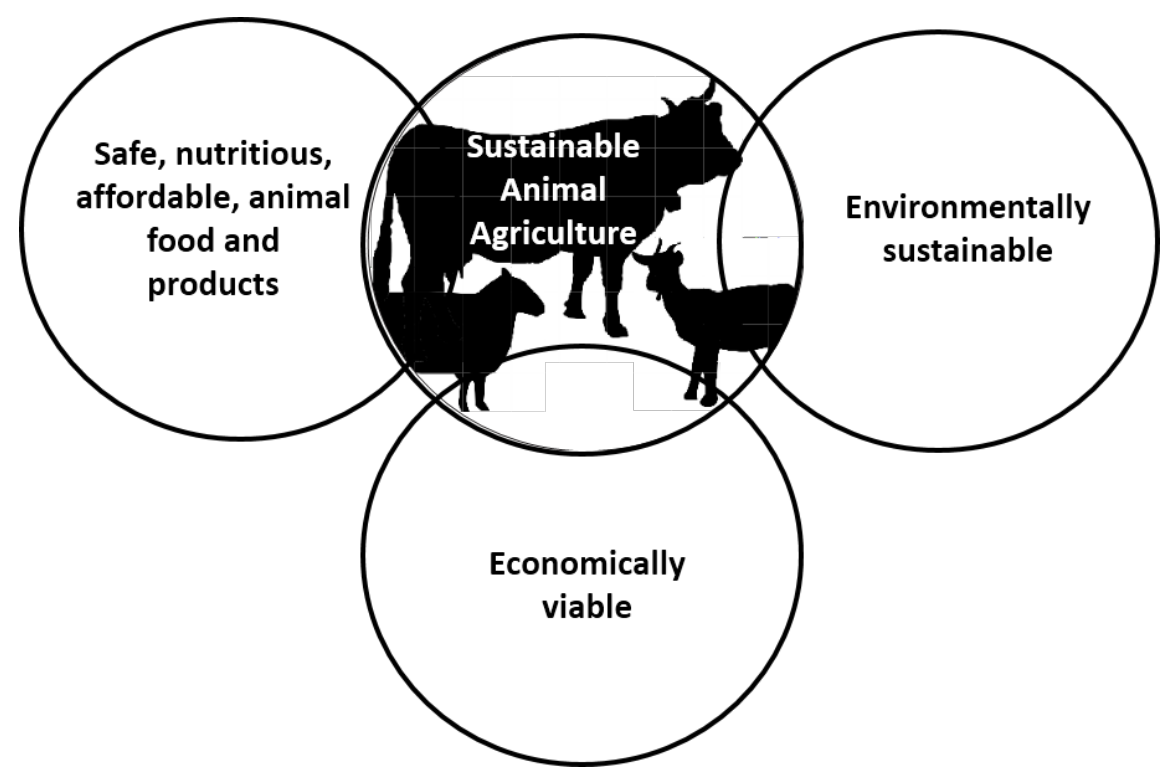

Figure 4 Climate-smart, sustainable animal agriculture Source: Kadzere, 2017

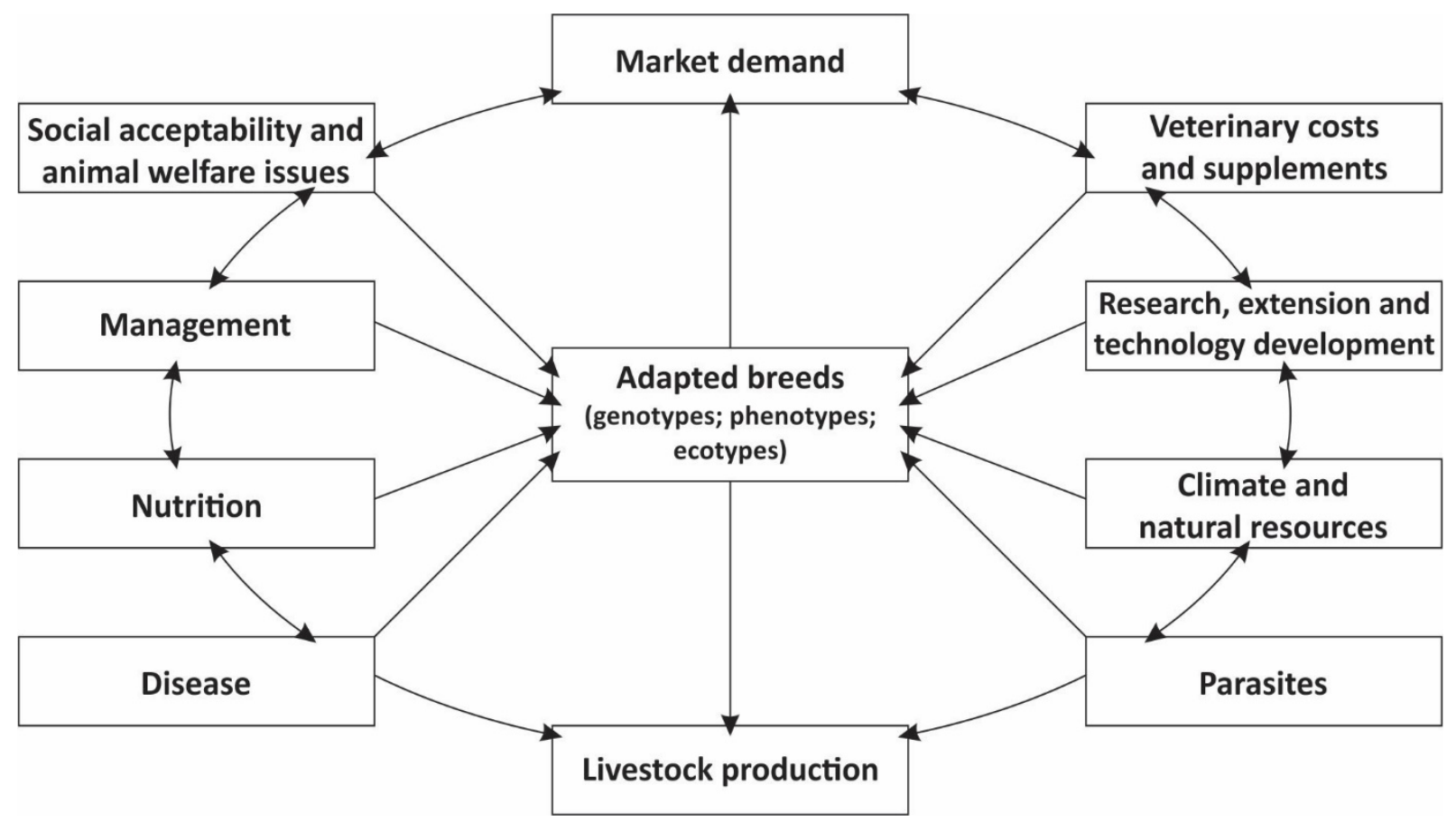

Figure 5 Factors influencing the livestock production environment Source: Kadzere, 2017

\section{Adaptations to survive and produce}

Each of the 150 or so Bos taurus and Bos indicus African cattle breeds has adapted to its environment through centuries of natural selection (Mwai et al., 2015). Temperate breeds selected for meat and milk must acclimatize, if they are to produce in tropical and subtropical African environments (Buffum, 1909). 
Table 1 Sample of breeds with regional adaptations in sub-Saharan Africa (Source: DAGRIS, 2007)

\begin{tabular}{|c|c|c|}
\hline Group & Breed Name & Characteristics \\
\hline \multirow[t]{2}{*}{ Humpless longhorns } & Kuri & Excellent swimmers, intolerant to heat and sunlight \\
\hline & N'Dama & Tolerance to trypanosomiasis and cattle ticks \\
\hline \multirow[t]{2}{*}{ Humpless shorthorns } & Savanna Muturu & Sexual dimorphism on body size, well-fleshed body \\
\hline & Sheko & Tolerance to trypanosomiasis \\
\hline \multirow[t]{5}{*}{ Large East African zebu } & Barka & Active disposition \\
\hline & $\begin{array}{l}\text { Karamajong } \\
\text { zebu }\end{array}$ & Adapted to very dry climate \\
\hline & Kenyan Boran & $\begin{array}{l}\text { Walking ability, highly adapted to harsh conditions, herd instinct, } \\
\text { mothering ability, longevity, large sex dimorphism }\end{array}$ \\
\hline & Orma Boran & Tolerance to trypanosomiasis \\
\hline & Turkana & Survive on very poor pasture and scarce water, walking ability \\
\hline \multirow[t]{7}{*}{ Small East African zebu } & Angoni & $\begin{array}{l}\text { Adapted to browsing during dry season, variable coat colour and size } \\
\text { of horns }\end{array}$ \\
\hline & Arsi & Poor milkers, extremely active and often very aggressive \\
\hline & Jem-Jem & Well adapted to wet and cold climate \\
\hline & Mongolla & Expected tolerance to trypanosomiasis, well fleshed \\
\hline & $\begin{array}{l}\text { Nuba mountain } \\
\text { zebu }\end{array}$ & Dwarf, tolerance to trypanosomiasis \\
\hline & Ogaden & Good dairy and beef characteristics \\
\hline & Ugogo Grey & Adapted to browsing during dry season \\
\hline \multirow[t]{5}{*}{ West African zebu } & Azoquak & Very well adapted to drought \\
\hline & Red Fulani & Nervous and intractable temperament, poor milkers \\
\hline & Sudanese Fulani & Good walking ability \\
\hline & White Fulani & Good dairy and beef characteristics \\
\hline & Yola & Expected tolerance to trypanosomiasis, highly variable conformations \\
\hline \multirow[t]{2}{*}{ East African Sanga } & Bahima & Susceptible to rinderpest and trypanosomiasis \\
\hline & Raya-Azebo & Good draft power \\
\hline \multirow[t]{7}{*}{ Southern Africa Sanga } & Afrikaner & Walking and grazing ability, good mothering ability \\
\hline & Barotse & Docile temperament making it a good animal \\
\hline & Landim & $\begin{array}{l}\text { Well adapted to hot, humid weather as well as dry periods, very } \\
\text { resistant to Foot and Mouth Disease }\end{array}$ \\
\hline & Mashona & High fertility, strong maternal instinct, docile disposition \\
\hline & Nguni & $\begin{array}{l}\text { High fertility, early sexual maturity, good foraging and walking ability, } \\
\text { good mothering ability }\end{array}$ \\
\hline & Tswana & Tolerance to ticks, resistance to endemic heartwater \\
\hline & Tuli & High fertility, good mothering ability, low calf mortality \\
\hline \multirow[t]{5}{*}{ Zenga } & Alur & Thought to have trypano-tolerance \\
\hline & Arado & Docile, good work animal, low milk yield \\
\hline & Bovines of Tete & Thought to have trypano-tolerance \\
\hline & Fogera & Docile temperament \\
\hline & Horro & Calm disposition, variable milk production \\
\hline Recently derived breeds & Borgou & Sexual dimorphism \\
\hline
\end{tabular}

\section{Physical adaptations}

There are many stressors in sub-Saharan African environments that have led to the evolution of a rich genetic diversity of its livestock breeds (Burrow, 2012). Burrow (2012) determined the relationship between economic productive and adaptive traits in tropical and subtropical breeding programmes, and 
found that it was possible to improve genetic and adaptive traits simultaneously without compromising either. Burrow (2014) suggested a re-ranking of breeds across environments through use of breed type(s), phenotypes and ecotypes best suited to each habitat.

Zebu or humped cattle (Bos indicus) are the main type in sub-Saharan Africa (Hanotte et al., 2000). African indigenous taurine (Bos taurus) humpless cattle are exclusive to West Africa. These Bos taurus and Bos indicus breeds, including their crosses, the sanga (indigenous taurine and zebu) and zenga (zebu and sanga) are physically adapted to local environments, where European breeds are not (Rege, 1999). Sanga cattle have cervico-thoracic humps and are adapted to seasonally harsh environments of eastern and southern Africa (Okello \& Sabiiti, 2006). The rich genetic diversity of cattle in sub-Saharan Africa can be used to contribute to technology development for climate-smart livestock production if their productive efficiency is increased and hardiness retained.

\section{Physiological adaptations}

Bos taurus, zebu cattle and Bos indicus acquired genes that confer thermo-tolerance at physiological and cellular levels after the $B$. indicus diverged from $B$. taurus between 110,000 and 850,000 years ago (Bradley et al., 1996; MacHugh et al., 1997; Hansen, 2004).

Zebu breeds regulate their body temperature better when in thermal stress than European $B$. taurus breeds (Kadzere et al., 2002; Hansen, 2004), and have better overall production in tropical environments (Burrow, 2012). Further, zebu and zenga breeds, including the Karamajong zebu in Uganda, tolerate harsh environmental conditions such as very dry climates, in which they can drink only once in two days (Thomas, 1994). Similarly, Turkana cattle in Kenya can survive on poor pasture and scarce water, and can walk long distances (Rege et. al., 1999). Angoni cattle in Zambia and Ugogo Grey cattle in Tanzania are adapted to browsing during long droughts (Felius, 1995), whereas Landim cattle in Mozambique thrive in hot humid weather, and are tolerant to foot and mouth disease (Felius, 1995) (see Table 1).

The Jem-Jem cattle in Ethiopia are adapted to cold and wet conditions (Rege \& Tawah, 1999), as Dexter are in the Scottish Highlands. These are examples of physiological adaptations of indigenous livestock breeds to their environments which are invaluable to developing climate-smart livestock production strategies and technologies to mitigate climate change.

\section{Disease and parasite tolerance}

The $B$. taurus of sub-Saharan Africa are humpless shorthorns and longhorns that are smaller than zebu (Rege, 1999) and are uniquely adapted to harsh climate (Hansen, 2004), including being resistant to various endemic diseases (Murray et. al., 1984; Mattioli et al., 2000). For example, the N'Dama breed is tolerant to trypanosomiasis (Roberts \& Gray, 1973), whereas zebu are susceptible (Murray et al., 1982), although Njogu et al. (1985) reported some tolerance levels in East African Orma Boran breed. Trypanosomiasis is caused by T. Congolese, T. vivax and T. brucei spp., and occurs between $14^{\circ}$ north and $20^{\circ}$ south latitude (Steverding, 2008) and has suppressed economic and cultural development in Central Africa (Simarro et al., 2011). N'Dama (taurine) cattle show superior heat tolerance compared with zebu (indicine) and metabolize water more efficiently. This characteristic makes them better suited to hot and water-stressed regions (WISP, 2010).

The use of modern technologies, including genome-wide selection and gene-splicing, provides tools that can go a long way towards developing high-producing climate change-adapted phenotypes from indigenous breeds. Ticks and tick-borne diseases curb cattle production in Africa and throughout the world. Some Bos indicus breeds and their phenotypes show heritability of resistance to ticks (Table 2) compared with European taurine animals (Piper et al., 2009).

Table 2 Heritability $\left(h^{2}\right)$ ranges for adaptive traits in tropical-climate adapted beef and dairy cattle

\begin{tabular}{llll}
\hline Adaptive trait & No. of studies & Measure & $\mathrm{h}^{2}$ range \\
\hline Resistance to ticks & 10 & Tick count \& tick score & $0.05-0.44$ \\
Resistance to worms & 6 & Faecal egg count & $0.07-0.57$ \\
Resistance to heat stress & 6 & Rectal temperature & $0.12-0.33$ \\
Resistance to heat stress & 6 & Coat score & $0.08-0.64$ \\
Resistance to seasonal poor nutrition & 3 & Dry season weight loss & $0.14-0.34$
\end{tabular}

Sources: Prayaga et al. (2006); Burrow (2014) 
N'Dama and Ankole cattle are tick resistant in their habitats (Mattioli et al. 2000). Rege \& Tawah (1999) also found that Tswana cattle (sanga) had high tolerance to heavy tick infestations and were resistant to endemic heartwater, as did Asselbergs et al. (1993) in Landim cattle in Mozambique. The literature abounds in studies on disease, heat and parasite adaptations of cattle in Africa. This suggests that indigenous breeds can be exploited to mitigate climate change by breeding tick resistant or tolerant genotypes, as hypothesized.

\section{Mitigation strategies for climate change}

Research and technical progress will facilitate the development of strategies to mitigate climate change as better and deeper insights into the livestock genome, metabolome, proteome and microbiome compartments are gained (Thiruvenkadan, 2016). Such insights and advances in bioinformatics open new frontiers and possibilities to conducting holistic research that strengthens our understanding of the interplay among factors that influence animal production, including its genotype, nutrition, health, physiology, the environment, management, climate change, policy and politics. Those insights will enable the conception and development of mitigation strategies against climate change. Some of the technologies can be based on i) suppressing methanogens and reducing enteric methane $\left(\mathrm{CH}_{4}\right)$ production and improving efficiency, ii) feeding precision diets that reduce excreta and GHG emissions, iii) selecting appropriate genotypes and (iv) improving management.

\section{Genetic mitigation}

Major dairy breeds originated from temperate climates and high-producing cows are susceptible to heat stress in hot environments (Faquay, 1981; Kadzere et al., 2002; Srikandakumar \& Johnson, 2004) such as sub-Saharan Africa. High producing cows cannot achieve their genetic potential under heat stress, unless the environment is altered to control temperature.

Selecting heat stress resistant phenotypes and ecotypes within these breeds is slow owing to long generation intervals (Ravagnolo \& Misztal, 2000). However, Erbe et al. (2012) and Nguyen et al. (2016) used genomic selection for heat tolerance in dairy cattle to speed up genetic progress, and improved accuracy of genomic predictions. Similarly, Garner et al. (2016) used genomic technologies and genome-wide deoxyribonucleic acid (DNA) markers to identify mutations that influence variation in multi-gene traits such as heat tolerance. In an earlier work, Franks \& Hoffmann (2012) showed that a number of genes were associated with climate change adaptation, and concluded that genetic regulatory networks and epigenetic effects could be relevant to evolution. Recently the technology to gene-edit large animal genomes has opened new possibilities to mitigating climate change.

Indigenous cattle breeds underperform when compared with commercial breeds on narrow production traits such as beef and milk yield alone (Table 3). The picture changes once holistic comparisons are made that include multiple traits (Table 3) that influence production (Figure 5) in tropical and subtropical environments. Therefore, comparing indigenous breeds with commercial 'improved' breeds on a single characteristic is myopic, because it excludes other parameters that are important to economic livestock production. There is need to conduct trade-off analyses because the perceived production advantages associated with heterosis in $B$. indicus $x$ B. Taurus offspring come at a cost of loss to environmental adaptability, which is important in the light of climate change.

This suggests the need to develop regional breeding and selection programmes that involve adapted genotypes, phenotypes and ecotypes in specific environments. These may include Nguni and Tswana cattle in southern Africa, Boran and Umoja in East Africa and Fulani and N'Dama in West Africa (Table 1). These indigenous breeds have proved to be productive in their own environments and selecting and breeding from their high producing phenotypes and ecotypes would go a long way towards concentrating desired genes for production and tolerance to heat stress, and thus to mitigate climate change.

\section{Physiological mitigation}

Continuous advances in livestock performance physiology provide opportunities to increase beef production and lower the carbon footprint per unit product by for example treating feedlot cattle with $\beta$-adrenergic agonists (BAAs) (Stackhouse et al., 2012). Furthermore, in dairy, Capper et al. (2008) increased milk production and simultaneously reduced GHGs through application of recombinant bovine somatotropin (rbST). However, the use of these technologies is challenged by segments of society and animal welfare groups (Dohoo et al., 2003; SCAHAW, 1999). This makes it important for science, and not emotions and perceptions, to validate efficacy and food safety for such treatments. 
Table 3 Ranking of breed types for productive traits in temperate and tropical environments

\begin{tabular}{|c|c|c|c|c|c|c|}
\hline \multirow{2}{*}{ Breed type } & \multicolumn{2}{|c|}{ Bos Taurus } & \multirow{2}{*}{$\frac{\text { Tropical B. Taurus }}{\text { Sanga }}$} & \multicolumn{3}{|c|}{ Bos indicus } \\
\hline & British & Continental & & Indian & African & F1 Brahman x British \\
\hline \multicolumn{7}{|c|}{ Temperate environment } \\
\hline Growth & $\star \star \star \star ~$ & 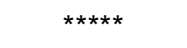 & 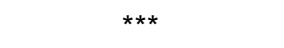 & $\star \star \star *$ & ** & $\star \star \star \star ~$ \\
\hline Fertility & 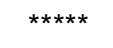 & 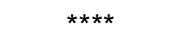 & $\star \star \star \star ~$ & $\star \star \star ~$ & 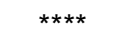 & 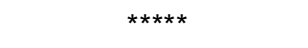 \\
\hline \multicolumn{7}{|l|}{ Tropical environment } \\
\hline Growth & $\star *$ & $\star \star$ & $\star \star \star *$ & $\star \star \star \star ~$ & $\star \star$ & $\star \star \star \star ~$ \\
\hline Fertility & ** & ** & 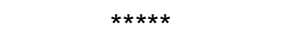 & $\star \star \star$ & 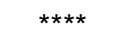 & 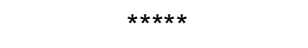 \\
\hline Mature Size & $\star \star \star \star ~$ & 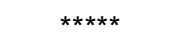 & $\star \star \star$ & $\star \star \star \star ~$ & $\star \star \star ~$ & $\star \star \star \star ~$ \\
\hline Meat quality ${ }^{\mathrm{M}}$ & 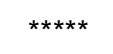 & 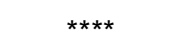 & 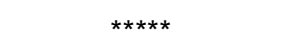 & $\star * *$ & 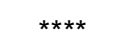 & 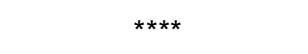 \\
\hline \multicolumn{7}{|c|}{ Resistance to environmental stressors } \\
\hline Cattle ticks ${ }^{\top}$ & * & * & $\star \star \star \star ~$ & 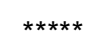 & 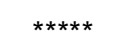 & 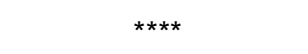 \\
\hline Worms $^{\mathrm{w}}$ & $\star \star \star *$ & $\star \star \star *$ & 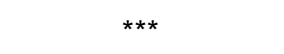 & 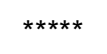 & 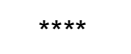 & 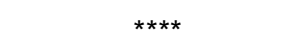 \\
\hline Eye disease & ** & 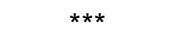 & 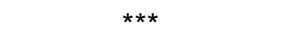 & 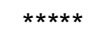 & 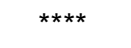 & 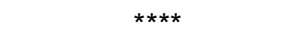 \\
\hline Heat & ** & ** & 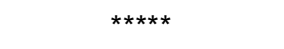 & $\star \star \star \star \star *$ & 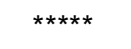 & $\star \star \star \star \star *$ \\
\hline Drought & $\star \star$ & * & 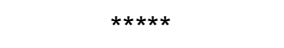 & 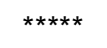 & 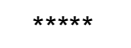 & $\star \star \star \star ~$ \\
\hline
\end{tabular}

Adapted from Burrow et al. (2001)

The more *s, the higher the value for the trait

${ }^{T}$ Rhipicephalus microplus

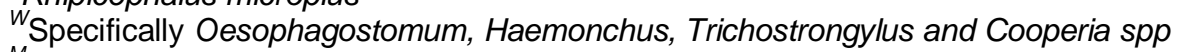

${ }^{M}$ Principally meat tenderness

\section{Nutritional mitigation}

About $65 \%-75 \%$ of variable costs in any livestock enterprise are ascribed to feed. Feed production accounts for $47 \%$ of the GHGs from livestock farming (Gerber et al., 2013). This makes animal nutrition a strategic target area to mitigate climate change because improving feed/forage quality improves digestion and reduces enteric $\mathrm{CH}_{4}$ production. Knapp et al. (2014) grouped enteric $\mathrm{CH}_{4}$ mitigation interventions in three categories: i) feeding and nutrient management, ii) rumen modifiers and iii) genetic and management.

Improving production efficiency through technical progress in nutrition and genetics leads to less feed and water consumed per unit of product, and this is climate smart. Kadzere et al. (2002) used USDA dairy production data from 1940 to 1995 and calculated that the average milk production per cow per 300-day lactation increased by 338\% from 2096 in 1940 to $7462 \mathrm{~kg} / \mathrm{year}$ in 1995. The increase was attributed to improved production efficiency by improved genetics, nutrition and management. Similarly, USDA (2007) calculated that the number of milk cows globally dropped from 133 to 125 million between 1997 and 2007, yet world milk production increased from 377 to 418 million metric tons, which translates to an $18 \%$ increase in production efficiency in that 10-year period.

Earlier on, Kriss (1930) reported strong associations between $\mathrm{CH}_{4}$ production and dry matter intake in cattle fed temperate forages, and showed that $\mathrm{CH}_{4}$ production was higher in cattle fed tropical forage diets, especially those on higher intake, than from the ones on temperate forages. That finding was validated by Van Soest (1994) and Reid (1994), who reported independently that the voluntary intake of forage is a factor of its digestibility and nutrient utilization. These authors attributed the higher $\mathrm{CH}_{4}$ production in cattle on tropical forages, as reported by Kriss (1930) to the poor digestibility of those forages compared with temperate ones, leading Van Soest (1994) and later O'Mara et al. (2008) to postulate that when the forage quality is improved, it lowers the life-time GHGs emissions per unit of animal product, owing to increased digestibility of feed and animal productivity.

Progress in nutritional technologies allows in-depth study of the gastro-intestinal microbiome and opens golden opportunities to manipulate methanogens and reduce enteric $\mathrm{CH}_{4}$ production. Reducing $\mathrm{CH}_{4}$ production would mean that more feed energy would be partitioned into the intermediary metabolism for more productive purposes, which improves feed efficiency. Enteric methanogenesis undermines efficient use of feed and should be minimized without disrupting proper rumen function, to mitigate global warming. 
To this effect, several technologies have been developed and are mentioned briefly. They include i) adding feed additives such as yeast (Chung et al., 2011), fibrolytic enzymes (Chung et al., 2012), ionophores (monensin) and rumen modifiers to enhance dry matter intake and suppress acetate production, which reduces the amount of hydrogen released (Odongo et al., 2006) and of plant bioactive compounds such as saponin (Holtzhausen et al., 2009) and inhibitors such as 3-nitrooxypropanol (Haisan et al., 2014); ii) adding dietary fat to lower enteric $\mathrm{CH}_{4}$ (Johnson et al., 2001) by reducing the amount of organic matter fermented in the rumen, curtailing rumen methanogen activity and through bio-hydrogenation of unsaturated fatty acids (Eugene et al., 2008); iii) feeding more concentrate than forages to reduce $\mathrm{CH}_{4}$ emissions (McAllister et al., 1996; Lovett et al., 2005); iv) increasing the corn silage content of diets, especially in dairy cow nutrition to lower $\mathrm{CH}_{4}$ production (Benchaar et al., 2001); v) ensiling forages at earlier regrowth stage, which leads to improved digestive efficiency and to reduced GHG emissions; and vi) grinding and pelleting forages before feeding, which lowers GHGs.

The emerging field of nutrigenomics (Figure 6) studies the ways in which bioactive chemicals in food and feed affect the animal's metabolism by altering gene expression. It brings together several disciplines, including bioinformatics, biology, epidemiology, epigenetics, genomics, functional genomics, molecular biology and nutrition (Benitez et al., 2017) and will provide technologies to feed according to the animal's genetic predisposition for production. That will lower GHGs emissions and excreta, thus nutrigenomics opens new opportunities to mitigate climate change nutritionally.

\section{Omics revolution}

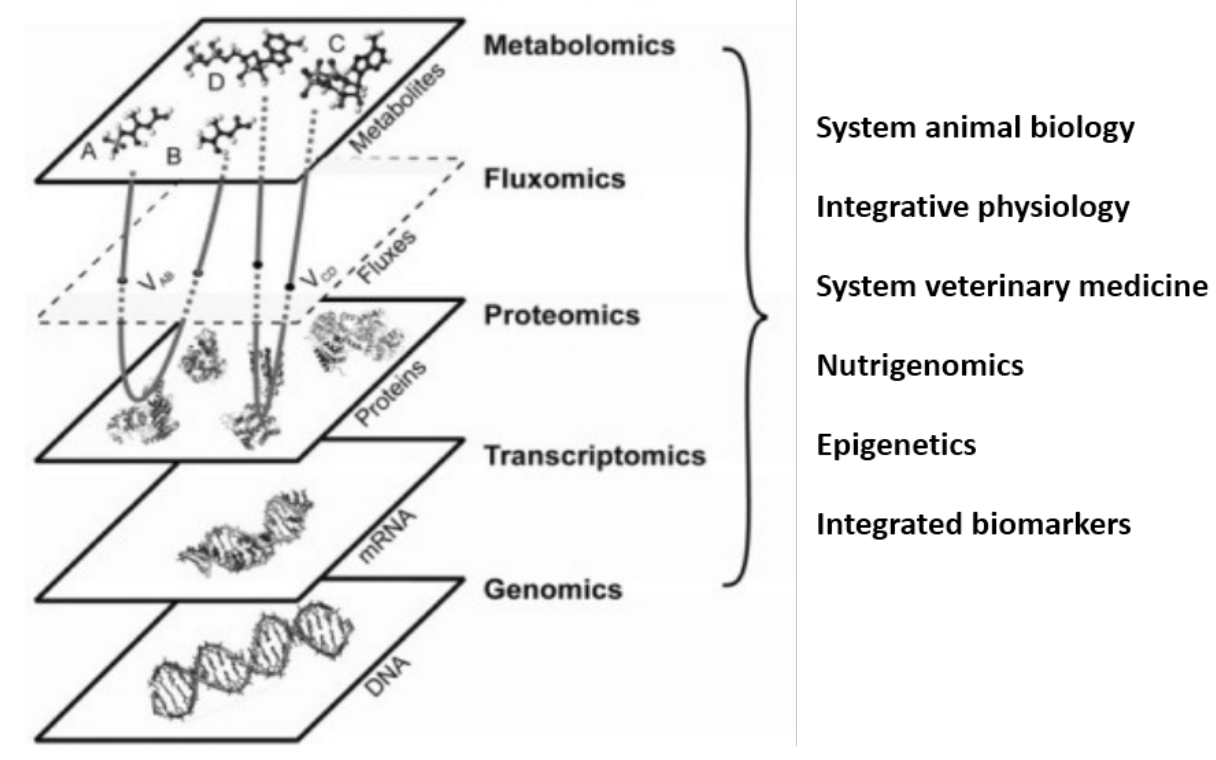

Figure 6 Nutrigenomics, a tool to mitigate climate change

Nutrigenomics provides opportunities to control gene expression through dietary means at any point on the pathway from packing and unpacking DNA to protein processing and degradation. Such possibilities provide opportunities to optimize diets and nutrient provision to livestock (Zdunczyk \& Pareek, 2009), which is climate-smart animal nutrition.

Although water is not strictly a nutrient, it is essential in livestock production, and 90\% of the 'water footprint' from animal products that originate from intensive systems is related to feed production (Mekonnem \& Hoekstra, 2014). Livestock on natural pasture, as in communal small-scale and extensive commercial production systems in sub-Saharan Africa, do not use extra water to produce pastures, which lowers the water footprint of their products and supports earlier findings by Scholtz et al. (2013).

\section{Advisory service mitigation}

Climate change poses complex challenges to animal agriculture that require integrated collaborative solutions from extension, research and training services (Figure 7). The phenomenon of climate change is new and requires people who serve in extension, research and training to continuously learn and upgrade their skills to keep pace with ever-changing sector norms and the expanding knowledge base. 


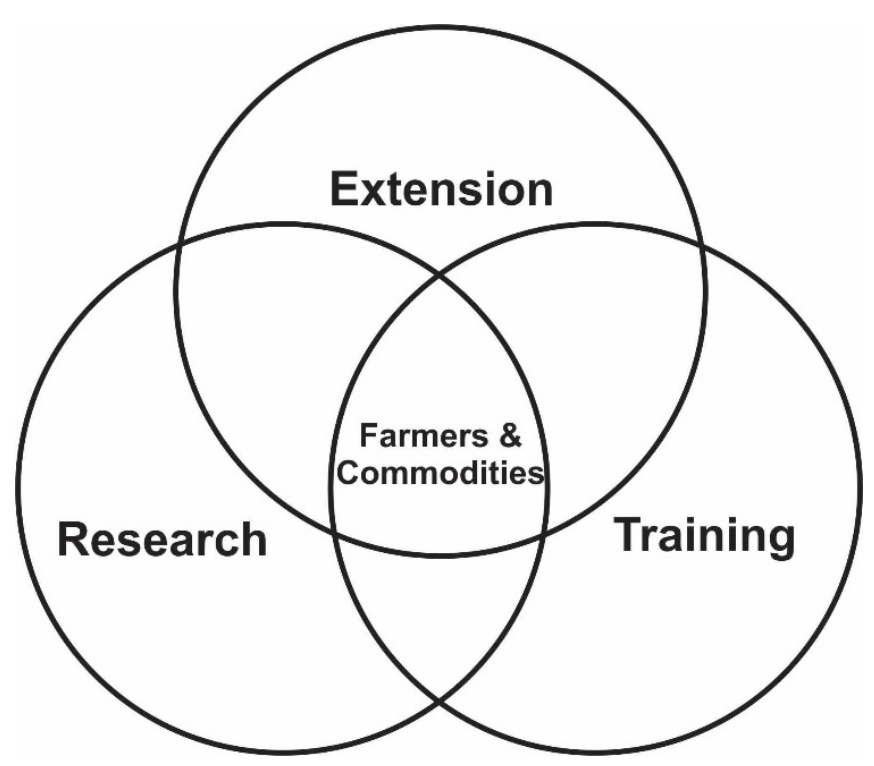

Figure 7 Integrated collaborative services delivery model Source: Kadzere \& Poswal, 2016

To be successful, collaboration in services delivery must be holistic, and involve all stakeholders, including the public, private and non-government sectors, government departments, producers, industry value chains and tertiary education institutions at local, national and international level (Figure 8). Climate change and livestock production and agriculture have local, national, regional and international dimensions that must be addressed concurrently because GHGs emitted in one country can influence production in another, and overproduction of a commodity in one locality affects prices elsewhere in the global marketplace.

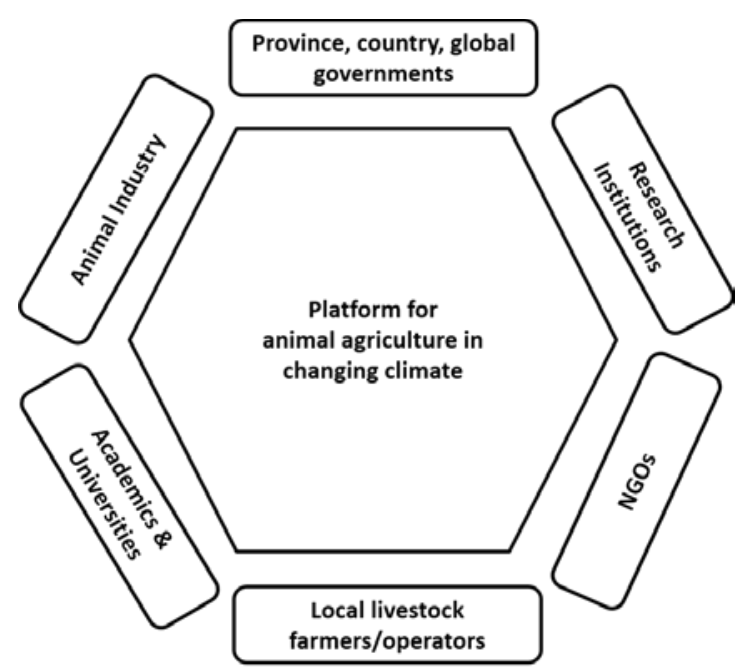

Figure 8 Platform to address climate change in livestock value chains

Source: Kadzere, 2017

Modern electronic communication technologies, including webinars and subject matter blogs, can bring stakeholders together in real time across disciplines, regions, countries and around the globe to collaborate, seek and find solutions to global warming and climate change. 


\section{Conclusions and future perspectives}

Environmental and climate-smart livestock production is guided by the animal's genotype and its environment. This allows optimum exploitation of the animal's inherent comparative production advantage in its environment, is 'in sync' with Darwin's theory that 'a grain in the balance will determine which individual shall live and which shall die', and reduces production costs. The interrelationships between the animal and its environment are at the core of successful livestock production. Animal production efficiency must be improved without compromising product quality, food safety, animal welfare and disease tolerance.

Climate change presents complex challenges that require integrated, interdisciplinary responses in research, extension and training. And yet, sub-Saharan African countries have unitary disciplinary extension and research in different government departments and training in tertiary education institutions. These entities do not collaborate, even though they share a common farming clientele. The unitary approach to agricultural services delivery in most of sub-Saharan Africa duplicates effort, is wasteful of resources, and is ineffective in addressing complex challenges posed by climate change that require inter- and multidisciplinary resolution. There is need to integrate services delivery, if mitigation against climate change is to succeed. The integrated collaborative research, extension and training services in livestock production will provide mitigation strategies and help farmers adapt by:

- Developing and sustaining climate-smart breeding programmes that use heat stress tolerantgenotypes and phenotypes with higher than average productive efficiencies and yet emit low GHGs per unit animal product

- Exploiting genome-wide nutritional technologies and practices such as precision nutrition and nutrigenomics to reduce the carbon and water footprints in livestock production value chains

- Applying advanced performance physiology technologies to stimulate muscle accretion in meat animals and enhance lactogenesis in dairy cows without compromising animal health but reducing GHGs emissions per unit product

- Seeking to understand how climate change affects the genotype and adaptation processes across and within livestock species

- Conducting holistic research that simulates the multiple stressors that simultaneously affect livestock and require multipronged resolution

- Developing and using accurate simulation models to predict the impact of climate change and conducting sensitivity analyses to find best options for farmers, and

- Collaborating within and across disciplines at local, national, regional and international levels and providing multi-faceted solutions to climate change in livestock production (Figure 8).

\section{Acknowledgements}

The author is grateful to colleagues at Döhne Agricultural Development Institute for an environment that is conducive to excellence in agricultural research and technology development, and to Karen Puchert for assisting with diagrammatic illustrations in this paper.

\section{Conflict of Interest Declaration}

The author declares that there is no conflict of interest.

\section{References}

Asselbergs, M., Jongejan, F., Langa, A., Neves, L. \& Afonso, S., 1993. Antibodies to Cowdria ruminantum in Mozambican goats and cattle detected by immunofluorescence using endothelial cell culture antigen. Trop. Anim. Health Prod. 25, 144-150.

Beauchemin, K.A., Kreutzer, M., O’Mara, F. \& McAllister, T.A., 2008. Nutritional management for enteric methane abatement: a review. Aust. J. Exp. Agric. 48, 21-27.

Benchaar, C., Pomar, C. \& Chiquette, J., 2001. Evaluation of dietary strategies to reduce methane production in ruminants: a modelling approach. Can. J. Anim. Sci. 81 (4), 563-574.

Benitez, R., Nunez, Y. \& Ovlio, C., 2017. Nutrigenomics in farm animals. J. Investig. Genomics. 4(1):00059. DOI: 10.15406/jig.2017.04.00059.

Bradley, D.G.., MacHugh, D.E., Cunnignham, P. \& Loftus, R.T., 1996. Mitochondrial diversity and the origins of African and European cattle. Proc. Natl. Acad. Sci. USA 93, 5131-5135.

Buffum, B.C., 1909. Arid agriculture: A handbook for the western farmer stockman. Self-published, Worland, WY, USA.

Burrow, H.M., 2012. Importance of adaptation and genotype $x$ environment interactions in tropical beef breeding systems. Anim. 6 (5), 729-40.

Burrow, H.M., 2001. Variances and covariances between productive and adaptive traits and temperament in a composite breed of tropical cattle. Livest. Prod. Sci. 70, 231-233.

Burrow, H.M., 2014. In: The genetics of cattle. $2^{\text {nd }}$ Edition. Edited by D.J. Garrick Department of Animal Science, Iowa State University, Ames, IA 50011, United States of America and A. Ruvinsky, University of New England, Australia, Chapter 23. CABI. https://www.cabi.org/bookshop/book/9781780642215. 
Capper, J., Castaneda-Gutierrez, E., Cady, R.A. \& Bauman, D.A., 2008. The environmental impact of recombinant bovine somatotropin rbST in dairy production. Proc. Natl. Acad. Sci. USA. 105-9668-9673. Doi: 10.1073/pnas.0802446105.

Chung, Y.H., Walker, N.D., McGinn, S.M. \& Beauchemin, K.A., 2011. Differing effects of two active dried yeast (Saccharomyces cerevisae) strains on ruminal acidosis and methane production in non-lactating dairy cows. J. Dairy Sci. 94, 2431-2439. Doi.10.3168/jds.2010-3277.

Chung, Y.H., Zhou, M., Holtshausen, L., Alexander, T.W., McAllister, T.A., Guan, L.L., Oba, M. \& Beauchemin, K.A., 2012. A fibrolytic enzyme additive for lactating dairy Holstein cow diets: Ruminal fermentation, rumen microbial populations, and enteric methane emissions. J. Dairy Sci. 95, 1419-1427. Doi:10.3168/jds.2011-4552.

Crick, F., 1970. Central dogma of molecular biology. Nature 227, 561-563.

DAGRIS (Domestic Animal Genetic Resources Information). Edited by S. Kemp, Y. Mamo, B. Asrat \& T. Dessie. International Livestock Research Institute, Addis Ababa, Ethiopia. http://dagris.ilri.org.

Darwin, C., 1859. On the origin of species by means of natural selection. John Murray, London, United Kingdom.

Dohoo, I.R., Leslie, K., DesCoteaux, L., Fredeen A., Dowling, P., Preston, A. \& Shewfelt, W., 2003. A meta-analysis review of the effects of recombinant bovine somatotropin: 1 . Methodology and effects on production. Can. J. Vet. Res. 67, 241-251.

Dowling, D.F., 1955. The hair follicle and apocrine gland populations of zebu (Bos indicus) L.) and Shorthorn (Bos taurus L.) cattle skin. Aust. J. Agric. Res. 645-654.

Erbe, M., Matukumali, B.J., Goswami, S., Bowman, P.J., Reich, C.M., Mason, B.A. \& Goddard, M.E., 2012. Improving accuracy of genomic predictions within and between dairy cattle breeds with imputed high-density single nucleotide polymorphism panels. J. Dairy Sci. 95, 4114-4129.

Escobosa. A., Coppock, C.E., Rowe Jr., L.D., Jenkins, W.L. \& Gates, C.E., 1984. Effects of dietary sodium bicarbonate and sodium chloride in physiological responses of lactating dairy cows in hot weather. J. Dairy Sci. 67, 574-584.

Eugene, M., Masse, D., Chiquette, J. \& Benchaar, C., 2008. Meta-analysis on the effects of lipid supplementation on methane production in lactating dairy cows. Can. J. Anim. Sci. 88, 331-337. Doi:10.4141/CJAS07112.

FAO (Food and Agriculture Organization of the United Nations), 2010. Livestock solutions for climate change. Gleam 2.0, reference year 2010, http://www.fao.org/gleam/results/en/, and http://www.fao.org/in-action/enteric-methane.

FASS (Federation of Animal Science Societies) FAIR (Farm Animal Integrated Research) 2012. [5 August 2014]. http://www.fass.org.docs/FAIR2012_Summary.pdf.

Faquay, J.W., 1981. Heat stress as it affects animal production. J. Anim. Sci. 52, 164-174.

Felius, M., 1995. Cattle breeds. An encyclopaedia. Misset, Doetinchem, Netherlands.

Franks, S.J. \& Hoffmann, A.A., 2012. Genetics of climate change adaptation. Ann. Rev. Genet. 46, 185-208.

Garner, J.B., Douglass, M.L., Williams, S.R.O., Wales, W.J., Marett, L.C., Ngyune, T.T.T., Reich, C.M. \& Hayes, B.J., 2016. Genomic selection improves heat tolerance in dairy cattle. Scientific Reports 6, 34114. DOI: 10.1038/srep34114. www.nature.com/scientificreports.

Gerber, P.J., Steinfeld, H., Henderson, B., Mottet, A., Opio, C., Dijkman, J., Falucci, A. \& Tempio, G., 2013. Tackling climate change through livestock - A global assessment of emissions and mitigation opportunities. Food and Agriculture Organization of the United Nations. Rome, Italy.

Gill, M. \& Smith, P., 2008. Mitigating climate change: The role of livestock in agriculture. Livestock and Global Change Conference Proceedings. 17-20 May 2008, Tunisia.

Haisan, J., Sun, Y., Guan, L.L., Larney, F.J., Beauchemin, K.A., Iwaasa, A., Duval, S., Barreda, D.R. \& Oba, M., 2014. The effects of feeding 3-nitrooxypropanol on methane emissions and productivity of Holstein cows in mid lactation. J. Dairy Sci. 97, 3110-3119. doi.3168/jds.2013-7834.

Hanotte, O., Tawah, C.L., Bradley, D.G., Okomo, M., Verjee, Y., Ochieng, J. \& Rege, J., 2000. Geographic distribution and frequency of a taurine Bos taurus and an indicine Bos indicus $Y$ specific allele among sub-Saharan Africa cattle breeds. Mol Ecol. 9, 387-396. [PubMed].

Hansen, P.J., 2004. Physiological and cellular adaptations of zebu cattle to thermal stress. Animal Rep. Sci.. 82-83, 349360.

Herrero, M. \& Thornton, P.K., 2013. Livestock and global change: Emerging issues for sustainable food systems. Proceedings of the National Academy of Sciences of the United States of America. 110 (52), 20878-20881. Harvard University, Cambridge, MA USA and at https://doi.org/10.1073/pnas.1321844111.

Hoffmann, I., 2010. Climate change and the characterization, breeding and conservation of animal genetic resources. Animal Genetics 41(Suppl. 1), 32-46.

Holtshausen, L., Chaves, A.V., Beauchemin, K.A., McGinn, S.M., McAllister, T.A., Odongo, N.E., Cheeke, P.R. \& Benchaar, C., 2009. Feeding saponin-containing Yucca schidigera and Quillaja saponaria to decrease enteric methane production in dairy cows. J. Dairy Sci. 92, 2809-2821.

Hristov, A.N., Oh, J., Lee, C., Meinen, R., Montes, F., Ott, T., Firkins, J, Rotz, A., Dell, C., Adesogan, A., et al., 2013. Mitigation of greenhouse gas emissions in livestock production - A review of technical options for non- $\mathrm{CO}_{2}$ emissions. FAO: Rome, Italy.

Huhnke, M.R. \& Monty Jr., D.E., 1976. Physiologic responses of prepaturient and post parturient Holstein-Friesan cows to summer heat stress in Arizona. Am. J. Vet. Res. 37, 1301-1304.

IPCC (Intergovernmental Panel on Climate Change), 2013. Summary for policymakers. In: T.F. Stocker, D. Qin, G.-K. Plattner, M.Tignor, S.K. Allen (eds).

IPCC (Intergovernmental Panel on Climate Change), 2013. The physical science basis 2013: Contribution of Working Group I to the Fifth Assessment Report of Intergovernmental Panel on Climate Change by Boschung, Nauels, Xia, Bev, Midgley et al. Climate change 2013: Cambridge University Press, New York, NY, USA. 
Johnson, K.A., Kincaid, R.L., Westberg, H.H., Gaskins, C.T., Lamb, B.K. \& Cronrath, J.D., 2001. The effect of oilseeds in diets of lactating cows on milk production and methane emissions. J. Dairy Sci. 85,1509-1515.

Kadzere, C.T., 2017. Environmentally smart animal agriculture and integrated advisory services ameliorate the negative effects of climate change on production. Unpublished invited paper presented to the 50th South African Society of Animal Science Annual Conference. 18-21 September 2017. The Boardwalk, Nelson Mandela Bay Metro, Eastern Cape, South Africa.

Kadzere, C.T. \& Poswal, M.A.T., 2016. South African agricultural extension: Is there need for a paradigm shift? Proceedings of the 50th Commemorative Conference of the South African Society of Agricultural Extension. 5-8 June 2016, Saint George Hotel, Centurion, Gauteng, South Africa.

Kadzere, C.T., Murphy, M.R., Silanikowe, N. \& Maltz, E., 2002. Heat stress in lactating dairy cows: A review. Livest. Prod. Sci. 77 (1), 59-91.

Knapp, J.R., Laur, G.L., Vadas, P.A., Weiss, W.P. \& Tricarico, J.M., 2014. Invited review: Enteric methane in dairy cattle production: Quantifying the opportunities and impact of reducing emissions. J. Dairy Sci. 97, 3231-3261. doi:10.3168/jds.2013-7234.

Kriss, M., 1930. Qantitative relations of the dry matter of food consumed, the heat production, the gaseous outgo and the insensible loss in body weight of cattle. J. Agric. Res. 40, 238.

Kugonza, D.R., Nabasirye, M., Mpairwe, D., Hanotte, O. \& Okeyo, A., 2011. Productivity and morphology of Ankole cattle in three livestock production systems in Uganda. Anim. Gen. Res. 48, 13-22.

Lovett, D.K., Stack, L.J., Lovell, S., Callan, J., Flynn, B., Hawkins, M. \& O'Mara, F.P., 2005. Manipulating enteric methane emissions and animal performance of late-lactation dairy cows through concentrate supplementation. J. Dairy Sci. 88, 2836-2842.

MacHugh, D.E., Shriver, M.D., Loftus, R.T., Cunnignham, P. \& Bradley, D.G., 1997. Microsatellite DNA variation and evolution, domestication and phylogeography of taurine and zebu cattle (Bos taurus and Bos indicus). Genetics 146, 1071-1086.

Mattioli, R.C., Pandey, V.S., Murray, M. \& Fitzpatrick, J.K., 2000. Immunogenetic influences on tick resistance in African cattle with particular reference to trypanotolerant N'Dama (Bos taurus) and trypanosusceptible Gobra zebu (Bos indicus) cattle. Acta Trop. 75, 263-277.

McAllister, T.A., Okine, E.K., Mathison, G.W. \& Cheng, K.J., 1996. Dietary, environmental and microbial aspects of methane production in ruminants. Can. J. Anim. Sci. 76, 231-243.

Mekonnen, M.M. \& Hoekstra, A.Y., 2014. The Netherlands: UNESCO-IHE: The Green, Blue and Grey Water Footprint of Farm Animals and Animal Products, Value of Water Research Report Series No 48. http://www.waterfootprint.org/Reports/Report-48WaterFootprint-AnimalProducts-Vol1.pdf.

Meissner, H.H., Scholtz, M.M. \& Palmer, A.R., 2013a. Sustainability of the South African livestock sector towards 2050. Part 1: Worth and impact of the sector. S. Afr. J. Anim. Science. 43, 282-297.

Meissner, H.H., Scholtz, M.M. \& Engelbrecht, F.A., 2013b. Sustainability of the South African livestock sector towards 2050. Part 2: Challenges, changes and required implementations. S. Afr. J. Anim. Sci. 43, 298-319.

Minson, D.J., 1990. Forage in ruminant nutrition. Academic Press, New York, NY.

Murray, M., Morrison, W. \& Whitelaw, D., 1982. Host susceptibility to African trypanosomiasis: Trypanotolerance. Adv Parasitol. 21, 1-68.

Murray, M., Trail, J.C.M., Davis, C.E. \& Black, S.J., 1984. Genetic resistance to African trypanosomiasis. J. Infect. Dis. 149, 311-319.

Musa, L.M.A., Ahmed, M.A., Peters, K.J., Zumbach, B. \& Gubartalla, K.E.A. 2005. The reproductive and milk performance merit of Butana cattle in Sudan. Arch. Tierz. 48, 445-459.

Mwai, O., Hanotte, O., Kwon, Y-J. \& Cho, S., 2015. African indigenous cattle: Unique genetic resources in a rapidly changing world. Asian-Austral. J. Anim. Sci. 28, 911-921.

NASA, 2016. Causes of climate change: Natural causes of climate change. http://www.ces.fau.edu/nasa/module4/causes-2.php.

NASA, 2018. Long-term warming trend continued in 2017: NASA, NOAA. https://climate.nasa.gov

Ndumu, D.B., Baumung, R., Hanotte, O., Wurzinger, M., Okeyo, M.A., Jianlin, H., Kibogo, H. \& Solner, J., 2008. Genetic and morphological characterization of the Ankole Longhorn cattle in the African Great lakes region. Gen. Sel. Evol. 40, 467-490.

Nguyen, T.T., Bowman, P.J., Mekonnen, H.M, Pryce, J.E. \& Hayes, B.J., 2016. Genomic selection for heat tolerance to heat stress in Australian dairy cattle. J. Dairy Sci. 99, 2849-2862.

Njogu, A., Dolan, R., Wilson, A. \& Sayer, P., 1985. Trypanotolerance in East African Orma Boran cattle. Vet. Rec. 117, 632-636.

Odongo, N.E., Bagg, R., Vessie, G., Dick, P., Or-Rashid, M.M., Hook, S.E., Gray, J.T., Kebreab, E., France, J. \& McBride, B.W., 2006. Long-term effects of feeding monensin on methane production in lactating dairy cows. J. Dairy Sci. 90, 1781-1788.

Okello, S. \& Sabiiti, E.N., 2006. Milk production of indigenous Ankole cattle in Uganda as influenced by seasonal variations in temperature, rainfall and feed quality. Makerere Univ. Res. J. 1, 73-92.

O'Mara, F., Beauchemin, K.A., Kreutzer, M. \& McAllister, T.A., 2008. Reduction of greenhouse emissions of ruminants through nutritional strategies. In: P. Rowlinson, M. Steele, \& A. Nefzaoui (eds.). Proceedings of the International Conference on Livestock and Global Climate Change. British Society of Animal Science, Hammamet, Tunisia. 17-20 May, 2008. pp. 40-43.

Otten, D. \& Van den Weghe, H.F., 2011. The sustainability of intensive livestock areas (ILAS): Network system and conflict potential from the perspective of animal farmers. Int. J. Food. Syst. Dyn. 2, 36-51 
Parsell, D.A. \& Lindquist, S., 1993. The function of heat-shock proteins in stress tolerance: degradation and reactivation of damaged proteins. Ann. Rev. Gent. 27, 437-496.

Piper, E.K., Jonsson, N.N., Gondro, C., Lew-Tabor, A.E., Moolhuijzen, P., Vance, M.E. \& Jackson, L.A., 2009. Immunological profiles of Bos taurus and Bos indicus cattle infested with cattle tick, Rhipicephalus (Boophilus) microplus. Clin. Vac. Imol. 16, 1074-1086.

Prayaga, K.C., Barendse, W. \& Burrow, H.M., 2006. Proc. 8th World Cong. Genet. App. Livest. Prod. CD Rom No. 16-01.

Perez-Crespo, M., Pintado, B. \& Gutierrez-Adan, A., 2008. Scrotal heat stress effects on sperm viability, sperm DNA integrity, and the offspring sex ration in mice. Molec. Reprod. Dev. 75, 40-47.

Ravagnolo, O. \& Misztal, I., 2000. Genetic component of heat stress in dairy cattle, parameter estimation. J. Dairy Sci. 83, 2126-2130.

Rege, J.E.O., 1999. The state of African cattle genetic resources I. Classification framework and identification of threatened and extinct breeds. Anim. Genet. Res. Inf. 25, 1-25.

Rege, J.E.O. \& Tawah, C.L., 1999. The state of African cattle genetic resources II. Geographic distribution, characteristics and uses of present-day breeds and strains. Anim. Genet. Res. Inf. 26, 1-25.

Reid, R.L., 1994. Milestone in forage research (1969-1994). In: G.C. Fahey, Jr. (ed). Forage quality, evaluation, and utilization. ASA, Madison, WI. pp. 1-58.

Roberts, C.J. \& Gray, A.R., 1973. Studies on trypanosome-resistant cattle. II. The effect of trypanosomiasis on N'Dama, Muturu and zebu cattle. Trop. Anim. Health. Prod. 5, 220-233.

Rosegrant, M.W., et. al. 2009. Looking into the future for agriculture and AKST (Agricultural Knowledge Science and Technology). In: Agriculture at crossroads. Edited by B.D. McIntyre, H.R. Herren, J. Wakhungu \& R.T. Watson Island Press, Washington, DC. pp. 307-376.

SCAHAW., 1999. Report on animal welfare aspects of the use of bovine somatotropin. Scientific Committee on Animal Health and Animal Welfare: Available online: http://ec.europa.eu/food/fs/sc/scah/out21_en.pdf.

Scholtz, M.M., Van Ryssen, J.B.J., Meissner, H.H. \& Laker, M.C., 2013. A South African perspective on livestock production in relation to greenhouse gases and water usage. S. Afr. J. Anim. Sci. 43, 274-254.

Schroeder, C.P., 1993. "A land grant response". In: The Future of Agricultural Research and Extension: Policy Perspectives (pp. 29-35). Rural Policy Research Institute. (RUPRI) Report, University of Missouri-Columbia, MO, 65211, USA.

Seo, S. \& Mendelsohn, R., 2006. The impact of climate change on livestock management in Africa: A structural Ricardian analysis. CEEPA Discussion Paper No. 23, Centre for Environmental Economics and Policy in Africa, University of Pretoria.

Seufert, V., Ramankutty, N. \& Foley, J.A., 2012. Comparing the yields of organic and conventional agriculture. Nature 485 (7397), 220-234.

Sevi, A., Annicchiarico, G., Albenzio, M., Taibi, L., Muscio, A. \& Dell'Aquiila, S., 2001. Effects of solar radiation and feeding time on behavior, immune response and production of lactating ewes under high ambient temperature. J. Dairy Sci. 84, 629-640.

Shields, S. \& Orme-Evans, G., 2015. The impacts of climate change mitigation strategies on animal welfare. Anim. (Basel) Jun; 5(2), 361-394. https://www.ncbi.nlm.nih.gov/pmc/articles/PMC4494406/.

Simarro, P.P., Diarra, A., Ruiz Postigo, J.A., Franco, J.R. \& Jannin, J.G., 2011. The human African trypanosomiasis control and surveillance programme of the World Health Organization 2000-2009. The way forward. PLoS Negl Trop Dis 5 (2): e1007. Doi: 10.137/journal.pntd.0001007.

Srikandakumar, A. \& Johnson, E., 2004. Effect of heat stress on milk production, rectal temperature, respiratory rate and blood chemistry in Holstein, Jersey and Australian Milking Zebu cows. Trop. Anim. Health Prod. 36(7), 685-692. doi: 10.1023/B:TROP.0000042868.76914.a9.

Stackhouse, K.R., Rotz, C.A., Oltjen, J.W. \& Mitloehner, F.M., 2012. Growth-promoting technologies decrease the carbon footprint, ammonia emissions, and cost of California beef production systems. J. Anim. Sci. 90, 46-56.

Steinfeld, H.,Gerber, P., Wassenaar, T., Castel V., Rosales, M. \& de Haan, C., 2006. Livestock's long shadow: Environmental issues and options. Rome, Italy: FAO.

Steverding, D., 2008. The history of African trypanosomiasis. Parasites and vectors. 1:3. doi:10.1186/1756-3305-1-3.

Thiruvenkadan, A.K., 2016. Nutrigenomics in livestock: Emerging face of molecular nutrition to improve animal health and production. J. Fisheries Livest. Prod. 4, 2 (Suppl) http://dx.doi.org/10.4172/2332-2608.C1.005.

Thomas, L.F., 1994. Ecological costs of livestock grazing in western North America. Conserv Bio 8(3), 629-644.

Thornton, P.K., 2010. Livestock production: Recent trends, future prospects. Philos Trans R Soc Lond B. Biol Sci. 365, (1554) 2853-2867. doi:10.1098/rstb.2010.0134

Thornton, P., Herrero, M. \& Ericksen, P., 2011. [ 11 August 2014]. Livestock and climate change. Livestock Exchange Issue Brief 3).https://cgspace.cgiar.org/bitstream/handle/10568/10601/lssueBrief3.pdf.

United States Department of Agriculture, 2007. The number of milk cows in USDA 2007. Dairy 2007. Part II: Changes in the US dairy cattle industry, 1997-2007. Veterinary Services National Animal Health Monitoring System. Retrieved from https://www.aphis.usda.gov/animal_health/nahms/dairy.

USEPA (US Environmental Protection Agency), 1994. International anthropogenic methane emissions: Estimates for 1990. EPA 230-R-93-010. Office of Policy, Planning and Evaluation, US EPA. Washington, DC.

US Inventory: Greenhouse gas emissions and sinks: 1990-2004. April 2006. USEPA \#430-R-06-002.

Van Soest, P.J., 1994. Nutritional ecology of the ruminant, 2nd edition. Cornell University Press, Ithaca, NY 
Von Humboldt, A., 1849. Ansichten der Natur mit wissenshaftlichen Elaeuterungen. (Aspects of nature from different lands and different climates with elucidations). J.G. Cotta Publisher. Stuttgart, Germany.

WISP (World Initiative for Sustainable Pastoralism), 2010. Supporting adaptation to climate change in Africa's livestock sector. Briefing note, April 2010.

World Bank., 2009. Minding the stock: Bringing public policy to bear on livestock sector development. Report no. 44010GLB. Washington, DC.

Zdunczcyk, Z. \& Pareek, C.S., 2009. Application of nutrigenomics tools in animal feeding and nutritional research. J. Anim. Feed Sci., 18, 2-16. 